\title{
Preparation of powdered egg yolk using a mini spray dryer
}

\author{
Estudo da obtenção de ovo em pó usando mini spray dryer
}

\author{
Rene Maria IGNÁRIO ${ }^{1}$, Suzana Caetano da Silva LANNES ${ }^{1 *}$
}

\begin{abstract}
Powdered egg is used as an emulsifying agent in emulsion formulations. It is an excellent source of high quality protein, of which the yolk contains $44 \%$ and the egg white $56 \%$. Spray drying is a widely applied method for drying aqueous or organic solutions and emulsions in the chemical and food industries. Spray drying can be used to preserve food or simply as a rapid drying method. The objective of this work was to study the viability of obtaining powdered egg yolk powder using a Büchi B-190 Mini Spray Dryer. The egg yolk protein was evaluated by the semi-micro Kjeldahl method. It was concluded that the use of the Büchi B-190 Mini Spray Dryer to produce powdered egg yolk is perfectly feasible.

Keywords: spray dryer; powdered egg; egg yolk.
\end{abstract}

\section{Resumo}

Ovo em pó pode ser usado como agente emulsificante. É uma excelente fonte de alta qualidade protéica contendo $44 \%$ na gema e $56 \%$ na clara. Spray dryer é um método amplamente usado para secar soluções aquosas ou orgânicas, emulsões, na indústria química e alimentícia. Spray dryer pode ser usado para preservar alimentos ou simplesmente como um método rápido de secagem. O objetivo deste trabalho foi estudar a viabilidade de obtenção de gema de ovo em pó utilizando o Büchi B-190 Mini Spray Dryer. O teor de proteínas da gema de ovo foi analisado pelo método semi-micro Kjeldahl. Concluiu-se o uso do Büchi B-190 Mini Spray Dryer para a obtenção de gema de ovo em pó é perfeitamente viável.

Palavras-chave: spray dryer; ovo em pó; gema.

\section{Introduction}

Eggs perform multiple functions in making and processing foods - they emulsify as well as add color, tenderness and flavor. Powdered egg is used as an emulsifying agent in emulsion formulations, increasing their stability, properties and economy. It is an excellent source of high quality protein, $44 \%$ found in the yolk and $56 \%$ in the egg white ${ }^{3}$. In addition, powdered egg is widely used in processed foods thanks to its microbiological safety and reduced volume ${ }^{2}$.

The processes employed in the production of dried egg include pan drying, foam-drying, freeze-drying, and spray-drying, the latter being frequently used ${ }^{5}$ Guardiola. In this process, a liquid droplet is dried rapidly as it comes into contact with a stream of hot air. The small size of the liquid droplets allows for very rapid drying and the residence time of the material inside the spray dryer is in the order of seconds. The dried material is separated from air in a cyclone separator. The drying rate and the time required for drying depend on the temperature of the droplet being dried TOLEDO ${ }^{13}$. Heat can damage the product if contact with high temperature drying air is long, denaturing the egg yolk lipoproteins, a problem that has logically been related to poorer emulsifying properties MOROS ${ }^{10}$.

For a laboratory scale system, a small device such as the B-190 Mini Spray Dryer is particularly interesting to produce small volumes of product within a short time. This device can handle spray drying processes in $50 \mathrm{~mL}$ batch volumes and

Recebido para publicação em 6/11/2006

Aceito para publicação em 11/5/2007 (002038)

Departamento de Tecnologia Bioquímico-Farmacêutica

Faculdade de Ciências Farmacêutica, Universidade de São Paulo - USP,

Av. Prof. Lineu Prestes, 580, Cidade Universitária, CEP 05508-900,

São Paulo - SP, Brazil,

E-mail: scslan@usp.br

*A quem a correspondência deve ser enviada up to $1 \mathrm{~L}$ of solution per hour and, thanks to its glassware, makes the complete drying process from the two fluid nozzles down to the collection vessel visible. The product parameters resulting from this drying method are affected by the instrument settings, and are therefore usually optimized through trial and error BÜCHI ${ }^{1}$.

Because egg yolk functionality is determined mostly by its protein fraction, our study was aimed at determining the technical viability of using the Büchi B-190 Mini Spray Dryer to produce powdered egg yolk suitable for stabilizing mayonnaiselike emulsions.

\section{Materials and methods}

White eggs (120) were purchased in a single lot at a local supermarket and stored in a domestic refrigerator at $5{ }^{\circ} \mathrm{C}$.

The amount of protein was evaluated by the Kjeldahl technique, based on two replicates using the semi-micro procedure described by the Adolfo Lutz Institute ${ }^{8}$.

\section{Experimental}

The experiments were carried out using a Büchi B-190 Mini Spray Dryer, which operates by the same principle as the co-current flow atomizer, i.e., the sprayed product and drying air flow go in the same direction.

The operating ranges of the process variables were selected based on the results of several runs carried out with distilled water to determine how they affect the outlet temperature. The inlet air flow was $800 \mathrm{~L} / \mathrm{h}$. A $0.5 \mathrm{~mm}$ diameter nozzle was used. Table 1 lists the numbers used to control the process variables, since the operating conditions of the device were set based on the control panel settings and not on the actual values of the process variables. 
Table 1 - Numbers used to control the process variables.

\begin{tabular}{lccccccccc}
\hline $\begin{array}{l}\text { Process Variables Settings } \\
\text { Corresponding mean unity }\end{array}$ & & & & & & & & & \\
\hline $\begin{array}{l}\text { Pump Control } \\
\text { (Feed rate) }\end{array}$ & $\mathrm{PC}$ & 2 & 3 & 4 & 5 & 6 & 7 & 8 & 9 \\
$(\mathrm{~mL} / \mathrm{h})$ & 1.7 & 2.5 & 3.2 & 4.6 & 6.1 & 9.4 & 12.3 & 13.8 & 15.2 \\
\hline Aspirator Control & $\mathrm{AC}$ & 0 & 5 & 10 & 15 & 20 & & & \\
$\quad($ Vacuum) & $(\mathrm{mbar})$ & -11 & -17 & -22 & -30 & -40 & & & \\
\hline Heating Control & $\mathrm{HC}$ & 4 & 5 & 6 & 7 & & & \\
$\quad$ (Inlet air temperature) & $\left({ }^{\circ} \mathrm{C}\right)$ & 92 & 106 & 121 & 137 & & & \\
\hline
\end{tabular}

The liquefied egg yolk samples were quickly shaken to break down the agglomerate and facilitate pumping into the spray dryer.

The fresh egg yolk was diluted in distilled water in proportions of 50 and $25 \%$ w.w ${ }^{-1}$ egg yolk/water in preparation for spray drying.

A fractional factorial design $2_{V V}^{4-1}$ was chosen. The instrument setting instead of the actual value of the process variable was used to choose the factor level. Protein content was the dependent variable. Table 2 shows the factors and their levels used in the experimental design.

Table 2 - Factors and their levels for the fractional factorial design $2_{I V}^{4-1}$.

\begin{tabular}{lcccc}
\hline \multirow{2}{*}{ Factors } & \multicolumn{3}{c}{ Instrument setting } \\
\cline { 2 - 5 } & \multicolumn{3}{c}{ High level ( $)$} & \multicolumn{2}{c}{ Lower level $(+)$} \\
\hline 1: Inlet air temperature & 5 & $\left(\cong 106{ }^{\circ} \mathrm{C}\right)$ & & $\left(\cong 123{ }^{\circ} \mathrm{C}\right)$ \\
2: Liquid egg yolk flow & 2 & $(\cong 1.7 \mathrm{~mL} / \mathrm{min})$ & 4 & $(\cong 3.2 \mathrm{~mL} / \mathrm{min})$ \\
3: Vacuum & 0 & $(\cong-11 \mathrm{mBar})$ & 10 & $(\cong-22 \mathrm{mBar})$ \\
4: Egg yolk/Water dilution & $25 \% / 50 \%\left(\mathrm{w} \cdot \mathrm{w}^{-1}\right)$ & $50 \% / 50 \%\left(\mathrm{w} \cdot \mathrm{w}^{-1}\right)$ \\
\hline
\end{tabular}

\section{Results and discussion}

The protein content of the egg yolk before spray dying is shown in Table 3.

The results of the experimental design are given in Table 4 .

Table 3 - Egg yolk protein content before spray drying

\begin{tabular}{ccc}
\hline $\mathrm{N}$ & Mean & Std. Dev. \\
\hline 2 & $36.22 \%$ & $0.23 \%$ \\
\hline
\end{tabular}

With a $99 \%$ confidence interval $\left(\mathrm{CI}_{99 \%}\right)$, no significant factors were found since all the confidence intervals fell within the zero value, as indicated in Table 5.

The protein content of the egg yolk after spray drying was therefore calculated as the average of 21 independent runs in the spray dryer, as shown in Table 6 .

Table 5 - Effects of the Factorial $2^{4-1}$ using a 99\% confidence interval $\left(\mathrm{CI}_{99 \%}\right)$.

\begin{tabular}{lrc}
\hline \multicolumn{1}{c}{ Factorial $2^{4-1}$} & Effects & $\mathrm{CI}_{99 \%}$ \\
\hline Mean & $31.37 \pm 0.22$ & {$[+30.70 ;+32.04]$} \\
\hline Main effects & & \\
\hline 1: Inlet air temperature & $0.71 \pm 0.45$ & {$[-0.64 ;+2.05]$} \\
2: Liquid egg yolk flow & $-0.43 \pm 0.45$ & {$[-1.77 ;+0.91]$} \\
3: Vacuum & $0.97 \pm 0.45$ & {$[-0.38 ;+2.31]$} \\
4: Egg yolk/Water dilution & $0.44 \pm 0.45$ & {$[-0.90 ;+1.78]$} \\
Two-way interaction & & \\
$12=34$ & $-0.37 \pm 0.45$ & {$[-1.71 ;+0.97]$} \\
$13=24$ & $0.46 \pm 0.45$ & {$[-0.88 ;+1.80]$} \\
$14=23$ & $-0.71 \pm 0.45$ & {$[-2.05 ;+0.63]$} \\
\hline
\end{tabular}

Table 6 - Egg yolk protein content after spray drying.

\begin{tabular}{ccc}
\hline $\mathrm{N}$ & Mean & Std. Dev. \\
\hline 21 & $31.88 \%$ & 1.10 \\
\hline
\end{tabular}

The spray drying operation with fresh egg yolk was very complicated. Pumping was almost impossible because of the large amount of agglomerates and gel formation. Moreover, the yields were low because of the rapid agglomeration of semidried droplets. Part of these droplets adhered to the glassware of the drying chamber, forming a kind of gel that grew during the drying process, obstructing the visibility through the dry-

Table 4 - Results of the fractional factorial design $2_{I V}^{4-1}$.

\begin{tabular}{|c|c|c|c|c|c|c|c|c|c|}
\hline \multirow[t]{2}{*}{ Run } & \multicolumn{4}{|c|}{ Factors } & \multirow[t]{2}{*}{ Protein (\%) } & \multirow[t]{2}{*}{ Mean } & \multirow[t]{2}{*}{ Replication } & \multirow[t]{2}{*}{$v$} & \multirow[t]{2}{*}{ Variance } \\
\hline & 1 & 2 & 3 & 4 & & & & & \\
\hline 1 & - & - & - & - & 30.22 & 30.22 & 1 & 0 & - \\
\hline 2 & + & - & - & + & $31.24 ; 31.30$ & 31.27 & 2 & 1 & 0.0018 \\
\hline 3 & - & + & - & + & $31.08 ; 31.55$ & 31.31 & 2 & 1 & 0.1110 \\
\hline 4 & + & + & - & - & $31.03 ; 30.46$ & 30.75 & 2 & 1 & 0.1626 \\
\hline 5 & - & - & + & + & $31.80 ; 31.95$ & 31.87 & 2 & 1 & 0.0102 \\
\hline 6 & + & - & + & - & $34.83 ; 32.57 ; 32.30 ; 32.73 ; 33.01 ; 32.88 ; 32.63 ; 32.85$ & 2.98 & 8 & 7 & 0.6093 \\
\hline 7 & - & + & + & - & $30.12 ; 31.22$ & 30.67 & 2 & 1 & 0.6053 \\
\hline 8 & + & + & + & + & $31.91 ; 31.89$ & 31.90 & 2 & 1 & 0.0002 \\
\hline
\end{tabular}


ing chamber. Another part of the droplets dried and, due to their weight, fell into the drying chamber collector instead of moving to the cyclone.

Diluting the egg yolk in distilled water $(75,50$ and $25 \%$ w. $\mathrm{w}^{-1}$ egg yolk/water) solved this problem. In fact, the higher the dilution the greater the yield and the easier the drying operation. At the end of the trial and error runs it was decided to use 50 and $25 \%$ of egg yolk in water, but not the $75 \%$ of egg yolk, which produced a lower yield. These dilutions also produced agglomerates, but in smaller quantities.

Although the idea of adding water to a product prior to drying it to remove that water may seem strange, since doing so increases the time, energy and cost involved in an industrial operation, in the case of this device it appears to be a necessary condition when spray drying egg yolk, for the efficiency of the operation was excellent.

Due to the aforementioned operational problems and the numerous factors (at least 4), a full factorial experimental design was unfeasible. The decision therefore was to use a fractional factorial design $2_{I V}^{4-1}$ in which only an adequately chosen fraction of the treatment combinations required for the complete factorial experiment was selected to be run. Although the interpretation of the results is more difficult because the two-way interactions in this design are confused with each other, the design can easily be complemented to a full factorial one if the two-way interactions are significant.

The outlet air temperature is a product of the mixture of air, steam and dried particles before it enters the cyclone, which results from the mass and heat balance inside the drying chamber and which cannot be controlled. Due to the intense mass and heat transfer and moisture loss, we considered that the air, steam and particles were at the same temperature.

The outlet air temperature of the drying of egg yolk and of distilled water showed a slight discrepancy. This can be explained based on the assumption that atomized droplets are spherical in shape, having the same diameter and a homogenous composition because of the high water content of the samples before drying, so they are basically water droplets.

As soon as a droplet of the spray comes into contact with the drying air, evaporation takes place from the saturated vapor film which is quickly established at the droplet's surface. Due to the high specific surface area, the existing temperature and moisture gradients, intense heat and mass transfer lead to efficient drying. This evaporation causes the droplet to cool, reducing its thermal load. The design and air flow rate of the drying chamber determine the droplet's residence time in the chamber, so that the desired droplet moisture removal is completed and the product removed from the dryer before its temperature can rise to the outlet drying air temperature. Hence, there is little probability of heat damage to the product.

A statistical analysis of the experimental design used here indicated that the factors involved, namely inlet temperature, feed rate, aspirator flow and egg yolk dilution, did not significantly affect the protein content of the powdered egg yolk under the conditions of this study. However, it should be kept in mind that this finding applies only within the limits of the chosen experimental factors listed in Table 2 . Outside this range, new experiments should be designed.

A comparison of the protein content before and after spray drying (Tables 3 and 6 ) indicates that some protein denaturation occurred.

However, this study aimed to determine the technical viability of producing powdered egg using the Büchi B-190 Mini Spray Dryer, and this degree of denaturation was not considered sufficient to prevent the powdered egg from being used in the production of mayonnaise-like emulsions.

\section{Conclusions}

Our findings revealed no significant changes in the egg yolk protein content after spray drying. It was found that egg yolk must be diluted in distilled water to facilitate the operation, and that the higher the dilution the easier the operation and the higher the yield. We therefore concluded that the use of the Büchi B-190 Mini Spray Dryer to produce powdered egg yolk for stabilizing mayonnaise-like emulsions is perfectly feasible.

\section{Acknowledgements}

The authors acknowledge the financial support of CAPES (Brazil) for this research.

\section{References}

1. BÜCHI. Spray Drying. Mini Spray dryer B-290. Technical Data B-290. Disponível em http://www.buchi.com. Acesso em: 23 set. 2006.

2. CABONI, M. F. et al. Effect of processing and storage on the chemical quality markers of spray-dried whole egg. Food Chemistry, v. 92, n. 2, p. 293-303, 2005.

3. DEMAN, J. M. Principles of Food Chemistry. 3.ed.Gaithersburg: Aspen Publishers, 1999. 520 p. (A Chapman \& Hall food science book).

4. DEPREE, J. A.; SAVAGE, G. P. Physical and flavour stability of mayonnaise. Trends in Food Science and Technol., Amsterdam, v. 12, n. 5-6, p. 157-163, 2001.

5. GUARDIOLA, F. et al.Oxysterol formation in egg powder and relationship with other quality parameters. J. Agric. Food Chem, Columbus, n. 43, p. 1903-1907, 1995.

6. GUARDIOLA, F. et al. Oxysterol formation in spray dried processed and stored under various condition: prevention and relationship with other quality parameters. J. Agric. Food Chem, Columbus, n. 45, p. 2229-2243, 1997.

7. IGNÁCIO, R. M.; LANNES, S. C. S. Obtenção de ovo em pó pelo Spray Dryer Büchi-190 para produção de emulsões. Rev. Brasileira de Ciências Farmacêuticas, São Paulo, v. 39, supl. 3, p. $68,2003$.

8. LUTZ, INSTITUTO ADOLFO. Normas analíticas do Instituto Adolfo Lutz. 2. ed. São Paulo. 1976. v.1, p. 14-63.

9. MILLQVIST-FUREBY, A. Characterization of spray-dried emulsions with mixed fat phases. Colloids and Surfaces B: Biointerfaces, Amsterdam, n. 31, v. 1,p. 65-79, 2003. 
10. MOROS, J. E.; FRANCO, J. M.; GALLEGOS, C. Rheology of spraydried egg yolk-stabilized emulsions. Int. J. Food Sci. Technol., Oxford, n. 37, v. 3, p. 297-307, 2002.

11. NETO, B.B.; SCARMINIO, I. S.; BRUNS, R. E. Como Fazer Experimentos. Unicamp. 2002. 401 p. Campinas.
12. PÉREZ-CORREA, J. R. Modelling and control of a spray dryer: a simulation study. Food Control, Amsterdam, v. 6, n. 4, p. 219-227, 1995.

13. TOLEDO, R. T. Fundamentals of food process engineering. Westport: AVI, 1980, p. 370-372. 